\title{
ESPAZO CATALÁN E ESPAZO ÁRABE NALGÚNS POEMAS DE CUNQUEIRO
}

César Morán

Filólogo e músico

doi:10.17075/mucnoc.2014.040 

Forcadela, M. / T. López / D. Vilavedra (coords.) (2014): Mil e un cunqueiros. Novas olladas para un centenario, Santiago de Compostela, Consello da Cultura Galega. doi:10.17075/mucnoc.2014. pp. 803-822

\section{DE PINTURAS E RETABLOS EN MÚSICA: PAU CASALS EN PRADA}

O arroubo que sobre Cunqueiro exerceu sempre a beleza fixo que moitos dos seus poemas saísen da contemplación dun cadro, dun monumento, dunha praza ou de calquera mostra artística. Os seus innumerábeis artigos están cheos de referencias a pintores e obras de arte -nomeadamente renacentistas- e mesmo sutís comentarios e análises que despois van derivando no poético mundo do escritor.

No poema "Retrato: "Cabeza de home" de Antonello de Mesina» de Herba aqui e acolá (Cunqueiro 1980: 168) faise unha descrición dun dos retratos do pintor italiano, profundando nos adentros e na actitude burleira que mostra o personaxe, a través do cal se reflexiona sobre o tempo, o que non dura, a crueldade humana, etc. ${ }^{1}$. Xa nos temos referido en varias ocasións ao «Rondeau das señoras donas pintadas no ouso do Vilar, no século XIV, cheirando unha frol», de Dona do corpo delgado (1950), seguido do «Rondeau da dona enterrada en San Xohán de Badón, con dous anxos aos pés», do mesmo libro (Cunqueiro: 1980: $127,129)$, onde se leva a cabo o mesmo procedemento de creación poética e transmutación imaxinativa a partir da arte plástica.

En Herba aqui ou acolá (Cunqueiro: 1991) achamos o poema «Na seo vella» (p. 100), dos «Novos cantos de Lleida»:

$\mathrm{O}$ vento foxe atraveso da pedra

ou nun repente dentro dela,

ordenado en ondas, como o mar.

E se alguén o chama volve coma un can

doado a sere pedra.

1 Trátase do Ritratto d'ignoto marinaio, de Antonello da Messina, que se atopa no Museo Mandralisca de Cefalù, na costa siciliana. Para Dorinda Rivera (2003), estes sorrisos «actúan como un impulso imaxinativo nas ensońacións literarias de Cunqueiro, e através delas busca unha resposta ilusionante ante a comprobación da difícil barreira que separa os dos mundos: o real e o imaxinario, que o escritor case sempre conseguiu avir na súa produción, mais que con tanta dificultade conciliou na súa vida diaria». 
Os veos das noivas deixaron na hedra unha memoria de tímidas sorrisas, e onde foron as campanas fica unha curuxa, con ollos abertos, atenta ás horas que non hai. $\mathrm{Na}$ súa capela, os ratos corren por dedentro dos ósos dos Requeséns...

Pro quen habita e canta e vai e vén na Seo Vella, o vento é. Os longos asubíos saen a cabalo polos altos ventanás do claustro en forma de frol, e non embargantes po amarelo derramado dos sartegos ao chan.

E acolá embaixo, Lleida a carón do río, vestida de outono.

Outro exemplo é «O cirio pascual na Capella Palatina» (p. 122):

Fixeron falla aguias e bestas varias

e ponlas de arbres e algún home perdido pra facer unha esvelta columna de mármore branco, que reciba diante do altar da Capella Palatina o cirio pascual, con pinas de incenso decorado. (...).

Poetizar sobre un obxecto de beleza plástica ten a mesma función que facelo sobre personaxes míticas (Edipo, Danae, Penélope... Dagha, Bran), sobre pasaxes bíblicas (Paltiel...) ou sobre a cidade do poeta (p. 140):

Eu chamo aos mosegos que descen dos teus ollos até cubrir as pedras máis recentes.

En cada arbre a ponla onde aniñan os melros sangra lentamente, ao escoitar o vento que pasa» [...]

Comezarás a espreguizarte cando os anxos da Paula recollan o teu sono de bronce coas súas mans, e eu quixera estar entón a teu carón 
cun anaco de branco ceo nos beizos,

preguntándoche onde deixache a noite,

a choiva, o silencio e o vento.

Todo vén a conto de «Pau Casals en Prada» (Cunqueiro: 1991, 110), poema onde se xunta ese poetizar sobre a arte plástica (o dourado retablo) e a sentida homenaxe ao xenial violoncellista, compositor e director de orquestra que foi Pau Casals:

\title{
PAU CASALS EN PRADA
}

\author{
No medio do dourado retablo \\ o xigantesco San Pedro inclínase pra diante \\ e eu sei o porqué: \\ porque do cello de Casals saíu \\ unha frase que se volveu bolboreta \\ e Pedro séguelle o voo por saber \\ en que vide ou roseira de que columna \\ vai a pousarse. \\ -O bosque do retablo en abril florece \\ e en outono deita follas secas. \\ Co arco Pau Casals vainas apartando \\ as que se pousan nas cordas do seu cello.
}

Xosé Henrique Costas inclúe o texto na súa edición de 1991 (Herba aqui ou acolá) e cualifícao de "auténtica xoia lírica» (p. 31). Inclúeo no apartado "Cantos do Rosellón» ao lado de «Ao pé do Canigó», «En Cuixá» e «A dama de Carol»e dá como referencia da publicación destes cantos o Faro de Vigo, 31-3-1975.

A realidade aludida desde os versos non é outra que a da igrexa de Sant Pere de Prada, na comarca do Conflent, na Cataluña norte. Tal igrexa, principal monumento da vila de Prada (Prades na nomenclatura oficial francesa), ten orixes no século Ix. O campanario, cadrado, é románico do século XII e unha das partes conservadas do antigo templo, en tanto que o altar maior ten un espléndido 
retablo barroco do século XVII, obra realizada polo escultor catalán Josep Sunyer entre os anos 1696 e 1699. Neste monumental e fermoso retablo, de madeira policromada, salienta a imaxe de San Pedro triunfante, ocupando a parte central do retablo tanto en vertical como en largura. En tons purpúreos e dourados, leva mitra, báculo na man esquerda, e a dereita tena levantada con dous dedos ergueitos, o que, unido ao feito de estar sentado, lle dá un feitío de Pantocrator. Cunqueiro debeu de ficar impresionado e quen sabe se non errou ao observar a súa leve tendencia cara a diante!

Pau Casals, sempre comprometido coa paz e coa liberdade, opóndose a todo tipo de ditadura. Após a guerra civil do 1936, estivo dezasete anos exiliado en Prada antes de partir para San Xoán de Porto Rico. E foi en Prada, no Pireneo, ao pé do Canigó, onde recomezou as súas actuacións en directo, organizou numerosos concertos e fundou, en 1950, o festival de música que hoxe se mantén e leva o seu nome. Moitos dos concertos tiveron lugar na igrexa de Sant Pere de Prada, e isto vai circundando o cerne significativo e estético do noso poema.

Para valorarmos en toda a súa plenitude o poema de Cunqueiro, cómpre ter en conta tres aspectos: a xa antedita fascinación pola beleza plástica, o que para o escritor mindoniense significaba, como galego, o contexto da cultura catalá, e a propia intención de homenaxear a figura de Pau Casals. No que atinxe ao segundo aspecto, son cońecidas as súas relacións con Josep Pla, Joan Perucho, Pere Gimferrer, Josep Vergés -o seu editor- ou Néstor Luján, entre outros persoeiros da cultura catalá. Era consciente do interese que, mesmo para a cultura galega, tiña o contacto e o coñecemento do contexto catalán. Gustaba ademais da lingua catalá, na que creou en varias ocasións e da que traduciu para o galego non poucos textos 2 . Diriamos, en fin, que en Cataluña tivo Cunqueiro unha actividade pública e un recoñecemento indiscutíbel. Pois volvendo ao fío, ten aquí sentido transcribirmos o poema «Ao pé do Canigó» (p. 109), un dos catro antes citados que forman os «Cantos do Rosellón»:

Monte, pai de montes,

pai de augas e de homes,

2 Pódense ver os estudos de Xesús González Gómez, por exemplo Álvaro Cunqueiro, traductor (González Gómez: 1990). De grande interese é o libro Álvaro Cunqueiro e as amizades catalanas (Jordi Cerdá, Víctor Martínez-Gil e Rexina R. Vega (eds.): 2003), que recolle as actas do Congreso Internacional «Álvaro Cunqueiro a Catalunya». 
dende todas as voltas de todos os camiños

ollo a túa cabeza de neve.

Ben me decato de que estás escoitando

na tardiña en que dende Prada a Ceret

floreceron as cerdeiras,

os versos de Verdaguer.

Chéganche as verbas súas envoltas

e os teus ecos devólvenas aos vales

pra que as aprendan os merlos

-e o reiseñor, que chegará mañá.

O pico do Canígó foi obxecto do poema épico de Jacint Verdaguer onde louva o nacemento heroico das nacións catalás. Cunqueiro escribe o seu poema sabendo do valor simbólico desta montańa máxica e cita ademais «os versos de Verdaguer» en «floreceron as cerdeiras». E como mostra da crenza que Cunqueiro tiña na literatura como elemento construtor da identidade dos pobos, non está de máis lembrarmos as coñecidas mais sorprendentes palabras do escritor galego a respecto da Commedia de Dante, sobre o feito de que supostamente puido ser escrita en catalán e non en toscano: «Si el Dante hubiera escrito en catalán la Divina Comedia, nadie hubiera podido evitar una Cataluña independiente y soberana» (Cunqueiro: 1981).

O protagonismo de Casals no poema é evidente, até o punto de que se pode apreciar un personaxe real (Pau Casals, obxecto do canto) e un personaxe simbólico, San Pedro, tratado aquí como axente lúdico (máis que relixioso), case coa inxenua naturalidade con que eran tratadas a Virxe, os santos e os elementos relixiosos nas medievais Cantigas de Santa María. A composición do texto, en verso libre de arte maior -menos o terceiro e o oitavo, que fechan pequenos fraseos-, sintoniza co cariz épico-lírico, onde a voz poética enuncia, describe, argumenta e evoca. Os oito primeiros versos constitúen a primeira parte da estrutura, subdividida á súa vez en dúas: o «dourado retablo» deixa ver o "xigantesco San Pedro» que se inclina "pra diante» (primeira microunidade) e aquí aparece o eu poéticonarrativo que presenta (segunda microunidade) o centro temático e accional do texto: o motivo de que San Pedro se incline para diante é a sublimación da música de Casals. A linguaxe non ten máis remedio que transformarse para reflectir o prodixio: a interpretación do xenial músico é tan sublime que unha frase do seu 
violoncello se converte en bolboreta. Xa está o espazo presto para que o lector, por un lado, e o San Pedro desde o retablo anden á procura da sonora bolboreta. Onde ha de pousar? En que vide ou roseira das que poboan o florido retablo?

A segunda parte son os catro últimos versos, mais hai algo novo: o voo imaxinativo dos versos anteriores produciu o harmónico dunha nova metáfora, e é que agora o retablo xa é un bosque, que deixa paso ao mes predilecto do escritor (abril) e a un tempo non menos querido: o outono. Están as rosas de abril e tamén as follas secas que no outono de San Lucas leva o vento polas vellas rúas de Mondoñedo. Todo se transforma. Da igrexa de Sant Pere de Prada cada vez fica menos, só un aroma, unha lembranza, porque agora é o bosque e impóñense as leis da natureza. Mais a música continúa porque Pau Casals segue alí marcando esencia, afastando co seu arco as follas secas que o bosque deita e que se pousan nas cordas do seu violoncello.

\section{CANDO A FORZA DO CANTO FACÍA DESERTAR AOS GUERREIROS: UNHA CANCIÓN FOI PROHIBIDA NO SUR}

Unha canción foi prohibida no sur

Sob as lonas da jaima cheira a menta.

O frautista pasea tocando a carón dos faróis

aliñados nas alfombras.

A frauta imita paxaros que non hai

namentras a bailarina sae ao meio da tenda

empuxada polas palmas e as voces

que repiten dez ou cen veces o único verso da canción.

-A bailarina tende as mans pintadas

pra coller primeiro e rexeitar despóis

algo que vai e vén polo áer.

Da roda das mulleres sae o berro: sriiií!

O príncipe Beiruc inclínase ofrecéndome un vaso de té. 
-É unha canción do norde, marmuria ao meu ouvido:

«Muller fermosa, pideme unha cousa de precio»

di a letra.

Cando a cantaban nas jaimas do sur

os guerreiros do norde soñaban coas súas mulleres

e fuxían na noite, namorados desertores.

Publicouse por primeira vez en 1969 no diario Faro de Vigo. En 1974, González Garcés inclúeo na súa antoloxía Poesía gallega contemporánea e, máis tarde, en Herba aquí e acolá (Cunqueiro: 1980, 144).

Este poema vale xa polo título: rompedor, inquietante, suxestivo, nada convencional. Semella o título dun filme. A modernidade está desde o inicio nos tres segmentos que o título contén: «unha canción», «foi prohibida»e "no sur». Facer dunha "canción» o centro do poema lévanos ás fronteiras imprecisas da intertextualidade, esta vez con recendo claramente popular. O tema da prohibición, e máis aínda unido á canción, admite lecturas polisémicas acaso en Cunqueiro insospeitadas. A idea do sur fainos pensar hoxe en Borges, Lord Dunsany, Benedetti..., o de máis abaixo, o de mais alá, o que está lonxe. É un título narrativo. Conta xa unha historia que despois se conta e instala nel (nese sintagma: no sur) os elementos árabes dese espazo desértico de haima e alfombras onde se vai desenvolver a acción.

En poemas como este, di González Garcés, desaparece o poeta de cancioneiro onde para moitos Cunqueiro está cravado, «e aínda o vangardista e de influencia surrealista. Tórnase en poeta enteiramente persoal e de maior fondura» (González Garcés: 1974, 169). E se á narratividade antedita lle engadimos o feitío teatral que o poema presenta, estamos ante un dos textos máis innovadores tamén no que atinxe á confluencia de xéneros.

Do punto de vista métrico, o poeta prescindiu totalmente da rima, mantendo porén un ritmo que, sendo irregular, descansa sobre o hendecasílabo, que abre as dúas primeiras unidades do poema («Sobre as lonas da jaima cheira a menta» e «-A bailarina tende as mans pintadas») e abre tamén a idea dos tres versos finais: «Cando a cantaban nas jaimas do sur». «Providencialmente» aparecen os alexandrinos na transcrición da canción dun verso só («Muller fermosa, pídeme 
unha cousa de precio») e no verso que a presenta, comentándollo o príncipe Beiruc ao suxeito narrador do texto: «-É unha canción do norde, marmuria ao meu ouvido». O resto dos versos de arte maior -e menor- caracterízanse pola súa irregularidade, mais cómpre salientar a función rítmica de contraste e repouso que desempeńa o octosílabo no terceiro verso, cerrando a primeira escena da primeira unidade («alińados nas alfombras»), e esa forma octosilábica (ou heptasilábica) podémola captar tamén na segunda unidade, no final do terceiro verso que cerra a escena («...vai e vén polo áer»), así como no final absoluto do poema, que é tamén o final do terceiro verso do último enunciado: «...namorados desertores».

Todo indica que a irregularidade métrica non exclúe o equilibrio e mesmo unha certa simetría construtiva, así como un marcadísimo ritmo que tende ao ternario, un ritmo dactílico despois das sílabas en anacrusa ( $\mathrm{O}$ frautista pasea tocando a carón dos faróis»).

O texto, que pertence ao apartado "As historias» de Herba aqui e acolá, enmárcase na lińa culturalista árabe, ese mundo dos árabes do deserto, dos primeiros poetas islámicos como Al-Mutanabbi que tanto interese despertaron en Cunqueiro. Entre as variadas fontes e obras literarias con que se podería relacionar esta poesía están dúas inexcusábeis: a compilación de As mil e unha noites e o Sinbad do propio Cunqueiro. Este e outros poemas do noso autor ambientados no mundo árabe-oriental farían parte do mesmo mundo que ocupa un espazo importante da súa narrativa.

No entanto, a esencia temática do poema vai máis alá do revestimento ambiental, pois é a emoción producida por unha canción, que leva ao amor e afasta da guerra. $\mathrm{O}$ tema exponse no poema en dúas unidades estróficas, a canción e unha coda ou epílogo. O título funciona como algo máis que unha ambientación ao comezarmos a ler o texto, un texto dito por unha voz poética que non se manifestará até o final da segunda unidade, e esa será só unha das voces do poema.

O primeiro verso dá xa unha ambientación precisa: ese hendecasílabo perfecto que impón o ritmo. Todo transcorre dentro da haima co cheiro a menta que anticipa o "vaso de té». Entre os farois «aliñados nas alfombras» pasea tocando o frautista, e mentres este imita "paxaros que non hai» xorde no medio da tenda a bailarina, impulsada polas palmas e as voces que están a repetir sen parar a canción dun verso só. A canción xa se está a ouvir, mais o lector aínda non a coñece. A acción é dinámica desde o inicio e intensifícase aínda máis na segunda unidade. 
Coas mans pintadas de henna, a bailarina fai acenos a xeito de lampexos cegadores como para coller e rexeitar «algo que vai e vén polo áer». Entre tanto, as mulleres, en roda, fan o berro árabe, o zaghareet, coa súa estridencia aguda e o seu trémolo gutural. E aí é onde o príncipe Beiruc ofrece, inclinándose, un vaso de té ao convidado: a voz poético-narrativa, que se deixa ver/ouvir por primeira vez na primeira persoa.

Mentres lle ofrece o té, Beiruc convértese na voz que introduza e diga a canción dun só verso, e faino nos dous alexandrinos xa aludidos antes: o primeiro máis regular e o segundo máis abrupto:

-É unha canción do norde, marmuria ao meu ouvido:

"Muller fermosa, pideme unha cousa de precio».

A coda ou epílogo, que podemos ler aínda en boca do príncipe Beiruc ou ben entendela como palabras xa asumidas polo suxeito lírico e personaxe relator, ten un sentido lírico innegábel, mais tamén épico, co emprego do copretérito que inmobiliza a acción nun tempo mítico, cando os guerreiros desertaban da guerra, soñando coas súas mulleres, namorados, e todo pola forza inevitábel dunha canción. O norte e o sur, puntos cardinais equidistantes. No medio, unha canción, o amor e a guerra. Estamos outra vez ante a crenza no poder da palabra: a súa capacidade de incidencia e de transformación.

Sobre o papel que xoga o príncipe Beiruc no poema, e sobre a lectura do verso «-É unha canción do norde, marmuria ao meu ouvido», debemos facer algunhas consideracións. Desde sempre tiven para min que o verso en concreto comezaba cun verbo $(E)$ e non cunha conxunción. O feito de non estar graficamente acentuado é algo que encaixa no hábito normal de non acentuar as maiúsculas. Doutro xeito, a expresión carece de sentido. Imaxinemos a escena: hai un personaxe relator que se expresa en primeira persoa e que asiste ao espectáculo da haima convidado polo príncipe Beiruc. Este personaxe contempla o frautista imitando paxaros que non hai, contempla a bailarina na súa danza e igualmente escoita o berro das mulleres e mais as palmas e as voces que repiten incesantemente o único verso da canción. Entón, o príncipe Beiruc inclínase cara ao seu convidado e, mentres lle ofrece un vaso de té, explícalle que o que está a ouvir é unha canción do norte: «-É unha canción do norde, marmuria ao meu ouvido». E decontado faille a tradución: «Muller fermosa, pídeme unha cousa de precio». Iso é o que di 
a letra, acláralle. E mesmo lle relata o que acontecía aos guerreiros do norte cando tal canción era cantada nas haimas do sur.

Nada tería isto de particular se non fose porque nas máis das transcricións hai, ao meu ver, un erro de lectura. O poema fora publicado, como é sabido, o día 2 de novembro de 1969 no diario Faro de Vigo, e cinco anos despois, en 1974, Miguel González Garcés incorpórao, como dixemos, á súa antoloxía Poesía gallega contemporánea. Velaí o texto exacto da parte que agora nos interesa:

O príncipe Beiruc incrínase ofrecéndome un vaso de té.

-E unha canción do norde, marmuria ó meu ouvido:

"Muller fermosa, pideme unha cousa de precio»

di a letra.

A versión de 1980, en Herba aqui e acolá, é case idéntica á da citada antoloxía, só empregando a forma inclinase en vez de incrinase e a forma gráfica da contracción $a o$ en vez de ó. En todo caso, é relevante o feito de que nesta versión -onde tamén está a man amiga de González Garcés- se manteña con toda claridade a vírgula entre "unha canción do norde» e «marmuria ao meu ouvido», polo que de ningún modo se pode entender que o primeiro sintagma fose o complemento directo de marmuria. En rigor, o complemento directo incluiría o verbo $E$ que precede ao sintagma. Por outra parte, se González Garcés está detrás das dúas edicións, non hai dúbida de que a vírgula non é casual.

En 1983, César Antonio Molina reproduce o poema na súa Antología poética do autor mindoniense (Cunqueiro: 1983, 174) e tamén o inclúe despois na súa edición bilingüe Herba aqui ou acolá / Hierba aqui o allá (Cunqueiro: 1988, 34). En ambos os dous casos, reproduce con exactitude o texto de 1980, mais na páxina da dereita traduce para o español:

El príncipe Beiruc se inclina ofreciéndome un vaso de té.

-Y una canción del Norte, murmura a mi oído:

Hermosa mujer, pídeme algo de valor

dice la letra. 
Por máis que se pretenda, a expresión carece de sentido: o príncipe non pode dicir «Y una canción del Norte». Que dous segmentos, frases ou enunciados uniría esa pretendida conxunción copulativa $Y$ ? Dirá máis ben que se trata dunha canción do norte. A tradución debería ser «Es una canción del norte».

Na citada edición de 1991, (Herba aqui ou acolá) preparada por Xosé Henrique Costas, mantense en xeral o texto de 1980 no que atinxe a estes versos: a falta de acento gráfico no $E$, mais tamén, por suposto, a vírgula antes de marmuria. Coloca, iso si, outra vírgula despois de «unha cousa de precio» e antes de «di a letra», como na primeirísima edición do 69, o que non parece ter excesiva transcendencia á hora de interpretar o texto.

Cando en 1999 editamos o poema na nosa antoloxía Río de son e vento, colocamos acento gráfico sobre o $E$ ( É unha canción do norde, marmuria ao meu ouvido:»), coa certeza de estarmos a reproducir fielmente o sentido verdadeiro (Morán Fraga: 1999, 222). Poderiamos mesmo acrecentar que a música que compuxemos para o poema está feita a partir da rítmica que esta lectura provoca, mais iso é outra danza.

Todo chega ao limite cando no presente ano 2011 se edita en Galaxia a poesía de Cunqueiro entre 1933 e 1981 . Nesta edición, realizada por Xosé-Henrique Costas e Iago Castro Buerger -de grande interese pola incorporación de numerosos poemas dispersos e pola restauración da orde orixinal en Herba aqui e acolá-, elimínase sorprendentemente a vírgula que precedía a marmuria:

O príncipe Beiruc inclínase ofrecéndome un vaso de té.

-E unha canción do norde marmuria ao meu ouvido:

"Muller fermosa, pideme unha cousa de precio»,

di a letra.

Con este criterio, parece que se intentase perpetuar a lectura, para nós errada, que interpreta o $E$ como conxunción e non como verbo. Unha decisión para a que non encontramos fundamento (Cunqueiro: 2011).

Á vista do exposto, era necesario consultar o orixinal, no Faro de Vigo de 2 de novembro de 1969. As esperanzas non eran moitas, pois o máis probábel sería a non acentuación da vogal debido a un hábito máis ou menos instaurado. Mais a consulta facíase necesaria en todo caso. A sorpresa foi inmensa: a vogal non 
levaba acento gráfico, mais o verso aínda non era alexandrino, senón heptasílabo, porque a expresión «marmuria ao meu ouvido» simplemente non existía. Para alén doutras diferenzas entre este texto primeiro e o do 74 e 80 , os versos desta edición do 69 que agora nos interesan son así:

O príncipe Beiruc incrínase ofrecéndome un vaso de té.

-E unha canción do norde:

"Muller fermosa pideme unha cousa de precio»,

dí a letra.

Ou sexa, que as palabras «marmuria ao meu ouvido» foron engadidas por Cunqueiro con posterioridade, precedidas de vírgula, para que non houbese dúbida de que é Beiruc o que pronuncia a expresión «-É unha canción do norde», claramente unha oración con verbo copulativo. A intervención de Beiruc, mentres se inclina para lle ofrecer ao convidado un vaso de té, ten como función informalo de que esa canción que se está a repetir incesantemente na haima, e que todos están a ouvir, é unha canción do norte, cuxa tradución ou significado é «Muller fermosa pídeme unha cousa de precio». E mesmo pode inferirse que as palabras dos tres últimos versos:

Cando a cantaban nas jaimas do sur,

os guerreiros do norde soñaban coas súas mulleres

e fuxían na noite, namorados desertores

son tamén parte da intervención de Beiruc, como o minúsculo fragmento «dí a letra». Mais aquí xogan xa consideracións de tipo literario, pois o poema entra na súa fase anticlinal, epilogal e epifonemática, e neste proceso final parecen confundirse a voz do personaxe Beiruc e a voz poética e narrativa do poema (a voz do personaxe convidado) que tamén sería, se quixermos, a voz do autor.

E aínda máis. Volvendo á edición do 74, gustaría de saber se existe algunha publicación intermedia no decurso deses cinco anos que van desde o 69, porque non hai dúbida de que Cunqueiro modificou o texto, como é evidente. Fíxoo expresamente para a antoloxía de Garcés? Fíxoo antes? É un extremo que ignoro e sería moi feliz se alguén tivese a resposta e ma comunicase. O que si é certo é que foi González Garcés o primeiro responsábel do erro de lectura, pois a súa tradución na páxina da dereita é tamén 
-Y una canción del Norte, murmura a mi oído:

"Mujer hermosa, pídeme una cosa de precio»,

dice la letra,

adiantándose nove anos á versión de César Antonio Molina, sen descartar que este siga a daquel nese verso concreto, aínda que non na totalidade da tradución. Por que motivo Miguel González Garcés fai unha tradución contraditoria coa disposición gráfica do texto, que el mesmo respecta? Ignorámolo, mais cómpre aceptar circunstancias como o descoido, a interferencia de linguas e, por suposto, a vacilación gráfica da acentuación das maiúsculas.

Nese xornal do domingo 2 de novembro de 1969 a que fixemos referencia, o poema non aparece illado, senón facendo parte dos «Cantos do deserto» nas páxinas de LETRAS. Na páxina concreta, que é a 26, hai tamén unha crónica sobre o nobel literario Samuel Béckett, unha recensión sobre o libro Galicia feudal de Victoria Armesto e un artigo de Salvador Lorenzana (Fernández del Riego) titulado «Do mundo normal ó do manicomio». Os outros dous poemas que figuran como «Cantos do deserto» son "O pozo que non hai» e «Smara», e hai tamén unha pequena columna onde o propio Álvaro Cunqueiro escribe: «Istes poemas - urxentes vagancias da pruma - naceron con outros dunha viaxe do autor ó Sájara, a Al Aaiun i Smara, a cidade santa dos puritanos Al Ainin, na que aínda nos días en que estaba perdida e deserta, un mendiño tendía a man pedindo esmola. Van adicados a Muimelid Beiruc, unha fermosa princesa sajaraui, dos Abu Salah, que coido foi a pirmeira doncela do deserto que fixo de dama de honor nuns Xogos Florás. Na Sanguía al Hamra había i-auga, i as palmeiras abaneábanse no ar. Quitabas a sede co té, namentras escoitabas o xurdidor, que é a única ave que teñen acolá» (Cunqueiro: 1969). A estas palabras fai referencia Xosé Henrique Costas na súa edición Herba aquí ou acolá (1991). Damos por suposto, polo tanto, que viu o orixinal, mais nese caso non se comprende o seu proceder no texto «Unha canción foi prohibida no sur» na citada edición de 2011. Tamén fai referencia ao libro de Armesto Faginas Cunqueiro: unha biografía (1987) en cuxa páxina 166 hai unha foto de Cunqueiro con outras catro persoas, dúas con indumentaria árabe, e no pé de foto Armesto escribe: «Nunha visita ó Sahara, á volta da cal nos ofreceu "Os cantos do deserto" (Armesto Faginas: 1987, 166)». A citación de Costas inclúe a expresión «e debeu ser alá por 1969», que non figura 
no libro de Armesto Faginas, polo menos na edición de 1987. Todo indica, porén, que a viaxe foi nese ano.

Finalmente, temos que indicar que a citada páxina do Faro de Vigo inclúe unhas imaxes de danza árabe, ilustrando o(s) poema(s), co protagonismo da bailarina na que destacan as súas mans pintadas e as alfombras do chan. E como trazo de contexto, paratextual, case a xeito de brincadeira casual, na portada dese Faro de Vigo de 2-IX-1969 o titular primeiro di: «APOYO INCONDICIONAL DE ARGELIA A LOS COMANDOS PALESTINOS. "SUS ENEMIGOS SON LOS NUESTROS”, DICE BUMEDIAN EN UN DISCURSO» .

3 Bumedián, adaptación de Houari Boumédiène (1932-1978), en 1955 uniuse en Alxeria ao Exército de Liberación Nacional (ALN) e foi presidente do país desde 1965 até a súa morte. 


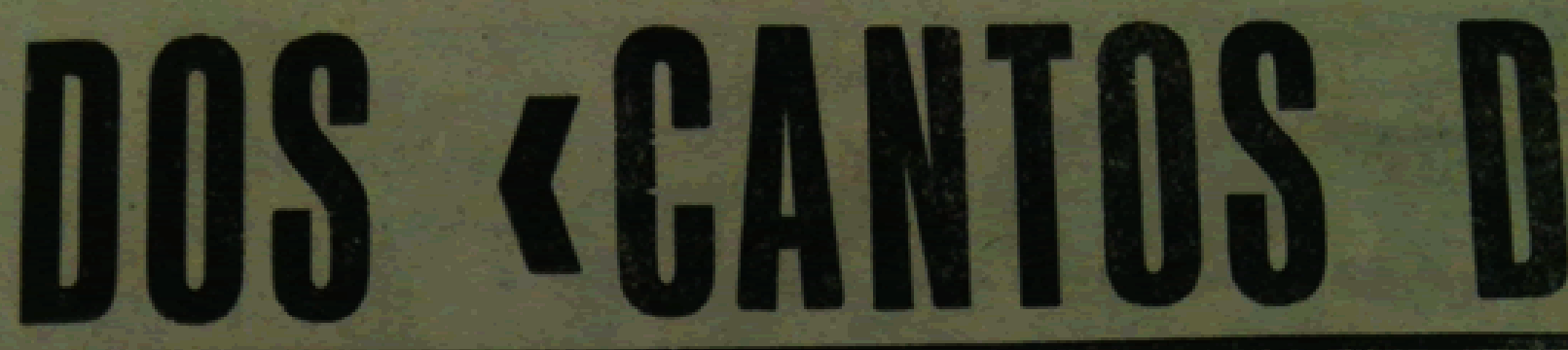

\section{UNHA CANCION FOI PROHIBIDA NO SUR}

Sob as lonas da jaima cheira a menta.

O frautista pasea tocando a carón dos farós, aliñados nas alfombras.

A frauta imita paxaros que non hai namentras a bailariña parez sair o meio e meio [da tenda empuxada pólas palmas $i$ as voces que repiten dez e cen veces o úneco verso da [canción.

\section{- A bailariña tende as mans pintadas} pra coller pirmeiro e rexeitar despoixas algo que vai $e$ ven pólo aer. Da roda das mulleres sae o berro: sritit O principe Beiruc incrinase ofrecéndome un vaso [de té. -E unha canción do norde:

"Muller fermosa pideme unha cousa de precio", di a letra.

Cando a cantaban nas jaimas do sur, os guerreiros do norde soñaban coas suas mulleres, e fuxian na noite, namorados desertores. 


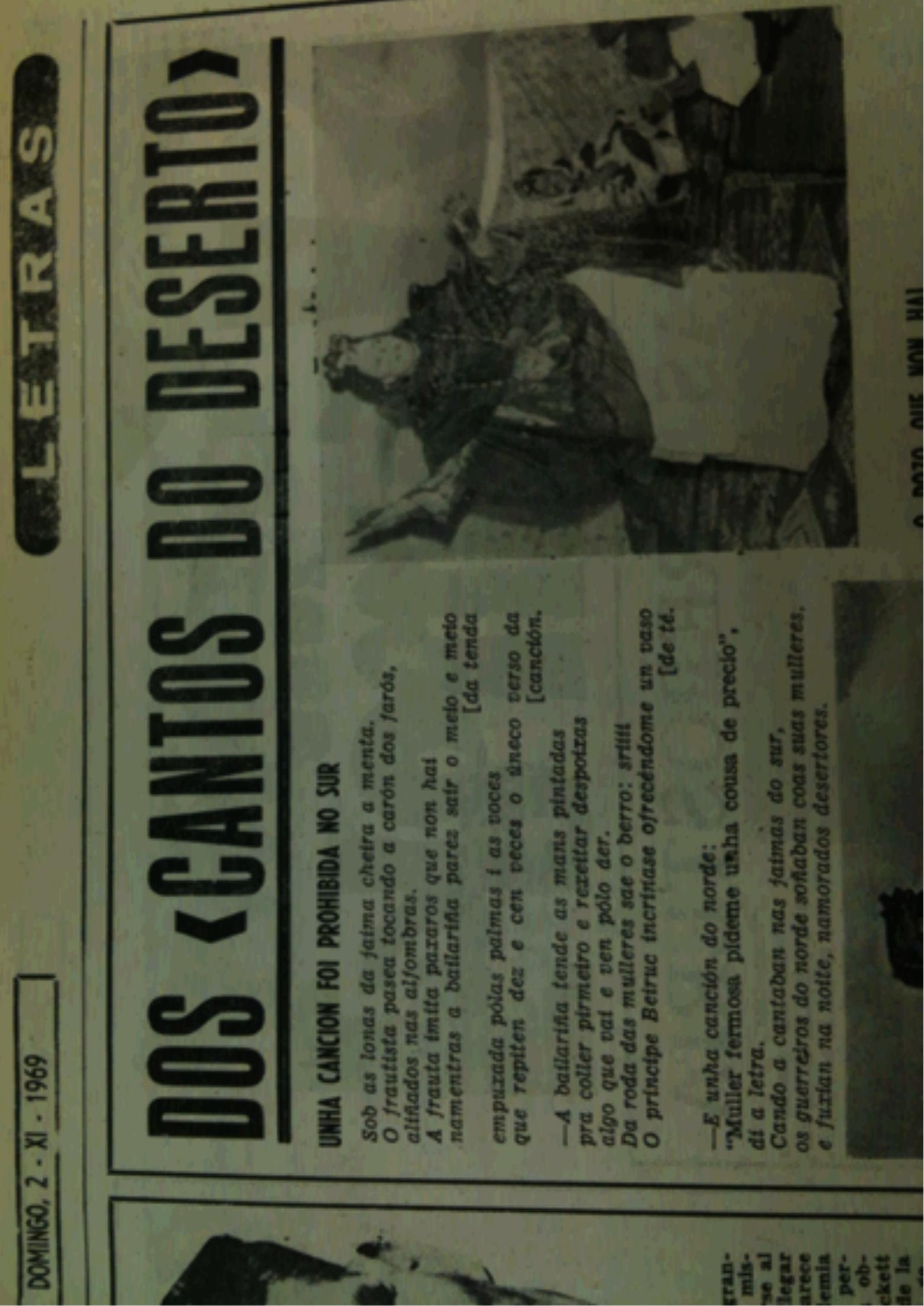



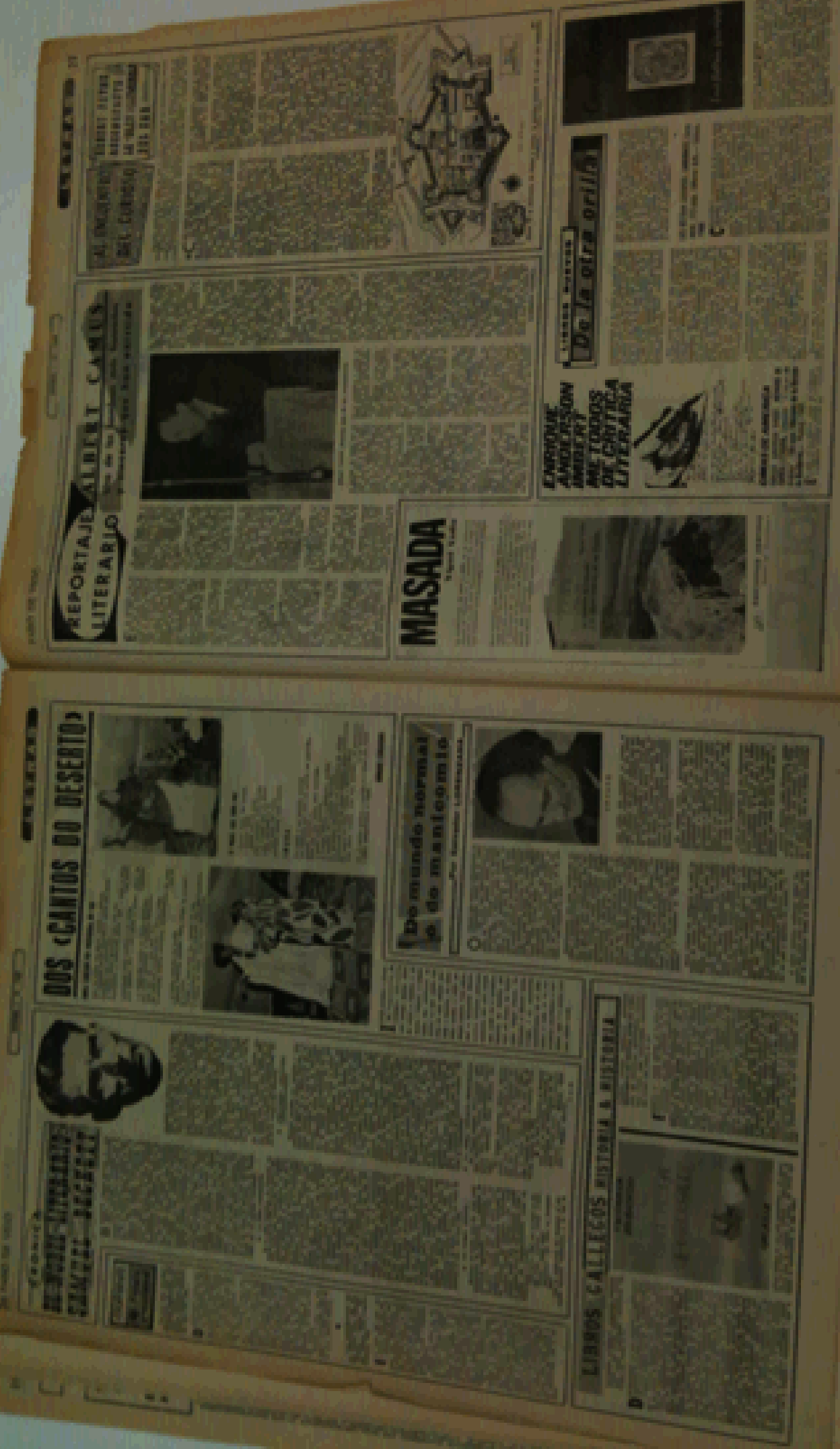


\section{REFERENCIAS BIBLIOGRÁFICAS}

Armesto Faginas, Xosé Francisco (1987): Cunqueiro: unha biografia (Vigo: Xerais).

Cerdà, Jordi, MARTÍNEZ-GIL, Víctor e R. VEGA, Rexina (eds.) (2003): Álvaro Cunqueiro e as amizades catalanas. Actas (Sada-A Coruña: Ediciós do Castro).

Cunqueiro, Álvaro (1969): «Dos Cantos do deserto», in Faro de Vigo, «Siglo II. Año 115», no 42549, Domingo, 2-XI-1969, Letras, páxina 26.

Cunqueiro Álvaro (1980): Obra en galego completa. Poesía-teatro I (Vigo: Galaxia).

Cunqueiro, Álvaro (1981): Nordés, II Data, 4, xullo 1981, p. 18.

Cunqueiro, Álvaro (1983): Antología poética (Texto bilingüe). Selección, Prólogo y Traducción de César Antonio Molina (Esplugues de Llobregat. Barcelona: Selecciones de Poesía Española, Plaza \& Janés).

Cunqueiro Álvaro (1988): Herba aqui ou acolá. Hierba aqui o allá (Edición Bilingüe). Tradución de César Antonio Molina (Madrid: Colección Visor. Ministerio de Cultura).

Cunqueiro, Álvaro (1991): Herba aqui ou acolá, edición comentada e aumentada por Xosé Henrique Costas González (Vigo: Galaxia).

Cunqueiro, Álvaro (2011): Dona do corpo delgado, Herba aqui e acolá, outros poemas, Poesía 1933-1981. Edición de Xosé-Henrique Costas e Iago Castro Buerger (Vigo: Galaxia).

González Garcés, Miguel (1974): Poesía gallega contemporánea (Esplugas de Llobregat: Plaza \& Janés).

González Gómez, Xesús (1990): Álvaro Cunqueiro, traductor (A Coruña: Caixagalicia).

Morán Fraga, César (1999): Río de son e vento. Unha antoloxía da poesía galega (Vigo: Xerais).

Rivera Pedredo, Dorinda (2003): «Algunas consideraciones sobre los pintores italianos del Renacimiento en la obra de Álvaro Cunqueiro", Centro Virtual Cervantes, Álvaro Cunqueiro, Varia cunqueiriana, Instituto Cervantes. 